\title{
Reconnecting Children with Nature: Founding and Growth of the Nature Schools Movement in Iran
}

\author{
Edgar Alan Burns ${ }^{1 *}$, Bahar Manouchehri ${ }^{2}$
}

1 University of Waikato, NEW ZEALAND
2 La Trobe University, AUSTRALIA
${ }^{*}$ Corresponding Author: edgar.burns@ waikato.ac.nz

Citation: Burns, E. A., \& Manouchehri, B. (2021). Reconnecting children with nature: Founding and growth of the nature schools movement in Iran. Interdisciplinary Journal of Environmental and Science Education, 17(3), e2244. https://doi.org/10.21601/ijese/10934

\begin{tabular}{|c|c|}
\hline ARTICLE INFO & ABSTRACT \\
\hline $\begin{array}{l}\text { Accepted: } \\
11 \text { February } 2021\end{array}$ & $\begin{array}{l}\text { The Nature Schools movement in Iran commenced in } 2014 \text { and expanded steadily for half a decade, } \\
\text { growing to almost } 100 \text { schools. Emulating similar educational inititives in Europe and North America, } \\
\text { Nature Schools offered outdoor educational experiences for pre-school and primary school years, } \\
\text { spreading across both metropolitan and regional Iran. Before the first Nature Schools were started, } \\
\text { detailed initial planning between academics and the government Environment Department and } \\
\text { Education Ministry was undertaken which projected the roll-out of many more Nature Schools. The } \\
\text { results of this study demonstrated that the establishment and growth pattern of the Iranian Nature } \\
\text { Schools had different causes stimulating its commencement, how these schools released a new } \\
\text { pedagogical practice for teachers, children and their families and how this movement offered an } \\
\text { alternative curriculum in nature with school children outdoors. Thus, despite the eclipse of the } \\
\text { Nature School movement, a longer time-frame indicates positive aspects, including the establishment } \\
\text { of green or eco-schools and the institutionalization of the environmental focus in pre-school } \\
\text { education. Many educators saw Nature Schools benefitting students' personal learning and academic } \\
\text { development. Political concerns after several years of growth led to some closures and slowing down } \\
\text { of the growth of Nature Schools in 2018-19. At the same time, a new national environmental } \\
\text { curriculum was being embedded across all age-levels of schooling in Iran. }\end{array}$ \\
\hline
\end{tabular}

Keywords: ecology education, environmental education, forest schools, Iran, nature schools, outdoor education

\section{INTRODUCTION}

Traditional cities of Iran developed organically and were adapted in architectural style to climate, nature and culture (Gharahbeiglu, 2007). Although Iran's traditional urban settings had no specific spaces for children, young people could play with their peers in local neighborhoods, learn social skills, enjoy new experiences and have contact with nature (Behroozfar, 2001; Gharahbeiglu, 2007). Since the Qajar Dynasty, modernization has changed the urban environment of Iranian cities. With the advent of modernity and destruction of the traditional texture of towns, especially high-rise buildings and densely populated neighborhoods in major cities, children's place in urban spaces is limited.

This study therefore aims to investigate the motivations and reasons of establishing Nature Schools in Iran and its growth pattern over the period of 2014-2019, and the confrontation of this movement with traditional approaches in education and alternative curriculum in the area of children's relationship with nature and outdoor space. The transformation of the living environment from traditional to modern, and the institutionalization of new urban patterns of life, have confined children to apartments and domestic spaces. A study by Hedayati (2018) confirmed this trend concerning the relation

Copyright (C) 2021 by Author/s and Licensed by Veritas Publications Ltd., UK. This is an open access article distributed under the Creative Commons Attribution License which permit unrestricted use, distribution, and reproduction in any medium, provided the original work is properly cited. 
between neighborhood physical environments and leisure activities of children aged 10-12 years in Tehran. The research showed that most children's activities were home-based rather than outdoors and that they spent most of their time at home.

However, this pattern is likely different between regions and within cities depending on high-income and middle-income areas shaping the presence of children playing in neighborhood public spaces. Modernization has also seen the creation of residential complexes in large cities designed around main arterial roads to facilitate traffic flows. These artificial environments are not based on the physical and psychological needs of children. Rather, social and economic issues have negatively affected children's safety in urban environments.

Today's Iranian child cannot adequately experience being in open city spaces (Mansouri \& Ghare Bigloo, 2012). Increased parental concern and reduced child presence in urban settings is shaped by insecurity in open urban spaces, leading children to retreat to private spaces. In 2011, Shokoohi, Hanif and Dali focused on the relation between the safety of neighborhoods and independent mobility of primary school children to and from school in Tehran. Results indicated that children and their parents who have negative perceptions concerning the safety of their living environment, tend to have their children escorted to school or use motor vehicles. Hence, unsafe urban environments restrict child mobility and, as Tonucci and Rissotto (2001) found, this situation, leads children to travel from one private place to another, such as home to school.

The lack of adequate urban services addressing children's needs is another reason for their absence in Iran's urban public spaces. Khodaee et al. (2015) found that there was a relation between youth satisfaction and access to services, social security and the physical specifications of their dwelling places. A study in the city of Yazd found urban per capita spending in this city in comparison to the population of children, does not meet the needs of this group; for example, children do not have the proper play equipment (Shahrizadeh \& Moayedfar, 2017). In Ardabil the views of 100 children in the fifth grade of primary school about their ideal places in the city, the state of the city, and the city they want, were examined. This study indicated that children do not play much outside the home in the city, and their range of activities is mainly limited to home and school (Imani, Yarmohammadi \& Yarmohammadi, 2017). Modernization has resulted in urban spaces that do not appropriately facilitate child presence and activity.

On the other side of the debate are narratives about global environmental degradation. Suidman
(2018, p. 5) argues that "Iran's environmental problem is among the most critical in the world." There have been school closures in the capital and other major cities due to high levels of air pollution and decline of urban green spaces due to land-use change and water crises (Staff, 2017; Novo, 2019; Tribune, 2017d). These issues have led to the formation of Nature Schools, a movement reflecting developments that had previously taken place in the Scandinavian context, US and UK as "Forest Schools" or in some cases "Nature Schools" (Pamuk \& Ahi, 2019; Swarbrick, Eastwood \& Tutton, 2004; Yates \& Oates, 2019).

The first Iranian Nature Schools commenced in 2014. These schools seemed, from both internal and international perspectives, to be a positive and relevant development as an emerging education strategy for the country. Nature Schools met the criteria of well-rounded pedagogy in child development by including the natural environment (Darling-Hammond et al., 2020). Nature Schools would enable children to reconnect with their physical, spatial and environmental roots. Education has long been a key strategy by or on behalf of developing countries establishing a viable modern society and economy (Lockheed, Verspoor et al., 1991; Sheykhi, 2009). This additional basis for enriched learning would allow students to better participate as future citizens in Iranian society experiencing environmental change (Sharifian, 2018).

The Nature Schools movement had government support, and positive reports about the performance of the initial schools encouraged further development. The schools addressed the excessively competitive national Iranian school culture in which education was for many a possible route out of poverty. For young schoolchildren the exploratory educational settings in Nature Schools offered different learning opportunities, literally grounding student learning in the environment of their school location. Indirect, creative, and exploratory learning experiences were emphasised. These features opened highly desirable pathways enhancing Iranian early and primary school education (Behroozfar, 2001).

Teachers enumerated multiple benefits evident in students' learning. For several years the Iranian Department of Environment promoted these schools as adding value to the educational system, complementing existing teaching and learning practices. The environmental messages of appreciating nature, experiencing nature in modest ways, being respectful of natural patterns and forces, and helping students to understand the need for 
humans to live sustainably, were straightforward and seen as beneficial.

The present article was prompted by research about the positioning of children in contemporary Iranian urban planning systems (Manouchehri, 2019). Planning in Iran has yet to overcome the cultural framing of children within traditional, topdown decision-making processes. The discussion of Nature Schools here describes one of the relatively few successful examples of educational innovation in Iran directly addressing children's needs.

\section{LITERATURE REVIEW}

\section{Children and Connection with Nature}

Nowadays, there is a global concern around lack of children's connection with nature and green spaces (Cumming \& Nash, 2015; O'Brien, 2009; Rantala \& Puhakka, 2020; Ridgers, Knowles \& Sayers, 2012' Harper, 2017). Lack of children's presence in natural green environments in any form has negative impacts on children's health and their social and physical development (UNICEF, 2018). Tillmann et al. (2019) argue that the significance of this issue is the extent it can lead to behavioral and socio-emotional problems associated with not being exposed to natural settings, known as "nature deficiency disorder" (NDD). The restricted child-nature relation is due to fear of accident or litigation, issues of risk and liability, and lack of adequate, safe and accessible outdoor natural settings (Lovell, 2009; O’Brien \& Murray, 2007). This issue has also led to fewer children having connections with outdoor play (Maynard, 2007).

Research shows that children spend less time playing outdoors than they did a generation ago (Arvidsen 2018; Harris, 2017; O'Brien 2009; Ridgers, Knowles \& Sayers, 2012). Children are raised with virtual play, electronic media, tablet, telephone and television, and engaged in more structured activities timetabled in afterschool clubs or activities-in closed spaces (Pamuk \& Ahi, 2019, Cumming \& Nash, 2015; Bal \& Kaya, 2020; Harris, 2017). A survey monitoring engagement in the natural environment in the UK suggests that disconnection from nature is more prevalent among children from lower socioeconomic classes and in urban environments (Harris, 2017). In urban areas that lack public and green spaces, children and their community do not have the amount and quality of space to play, congregate and socialize. This constrains the time and opportunities that children have to interact and build civic engagement (UNICEF, 2018).

There is a link between involvement with nature in childhood and the willingness to be involved with it in adulthood. One study indicates that if children do not visit woodlands and green spaces when they are young, they will become adults who do not use these spaces (O’Brien \& Murray, 2007; O’Brien, 2009). The child's connection with natural environments leads to social interaction, strengthens bonds within families and communities (Rantala \& Puhakka, 2020), and has a positive effect on personality, cognitive development and coping skills (Manner, Doi \& Laird, 2020). When childen's relationships with nature is accompanied by the elements of play, this leads to the growth of creativity, problem-solving, and emotional and intellectual development. The two-way relationship with nature, friends and peers, constructs new meanings for children (Harris, 2017). Playing in natural environments is also effective in th children's development due to the use of creative and imaginative ways of playing by children themselves (O’Brien \& Murray, 2007).

\section{Learning in the Context of the Natural Environment}

It is for these reasons of reconnecting school-age children with nature and play in natural settings, within the educational context, that Forest Schools and Nature Schools were established (Harper, 2017). The idea links children with nature and offers an alternative way of delivering the curriculum, and embedding outdoor learning pedagogies into the school's education framework (Cumming \& Nash, 2015). The movement utilized child-initiated and child-led activities, growing at the intersection of concepts of child, nature, play, place, story, experience, and learning (Pamuk \& Ahi, 2019; Harris, 2017, 2018; Blackwell, 2015; Leather, 2018; Harper, 2017). Forest Schools is an approach that provides children with regular opportunities to achieve and develop confidence and self-esteem through experience, play and practical learning in a natural environment (Cumming \& Nash, 2015; Harris, 2017; O'Brien \& Murray, 2007; O'Brien, 2009; Leather, 2018). In this process, natural elements such as trees, plants, soil, animals, air, and water are involved in learning and enable children to develop their understanding of natural areas during an exploratory process (Bal \& Kaya, 2020).

The foundation of this approach is related to theories such as Piaget's cognitive psychology, Locke's theory which emphasizes the interaction of students and environment, and the Montessori whole child theory of learning (Blackwell, 2015). The main characteristics of such kinds of schools are the same in all contexts. Each nation using Forest School programming adapts models and materials to be culturally relevant and adjusted to the philosophical underpinnings and training regimes that ensure continuity, quality, and societal relevance (Harper, 2017). For instance, in Denmark Forest Schools are known as "Nature Nurseries" and "Nature Schools" for primary aged children (Lovell, 2009). 
The activities of these schools focus on learning and experience in natural settings through play and teamwork (O’Brien, 2009; Harris, 2017). Children have the opportunity to engage in activities such as building a wooden shelter, lighting fires, climbing, playing environmental games, and identifying plants, animals, wildlife, and habitats (Lovell, 2009; O'Brien \& Murray, 2007; Ridgers, Knowles \& Sayers, 2012; Leather, 2018). Engaging with natural elements makes children use all their senses, and it improves language and communication skills since children engage in imaginative and fantasy play including storytelling (O'Brien, 2009; Leather, 2018; O'Brien \& Murray, 2007).

Natural or outdoor space has a great impact on the social, cognitive and emotional development of children and is effective on their mental and physical health (Arvidsen, 2018; Manner, Doi \& Laird, 2020; Blackwell, 2015). Forest and Nature Schools can also increase children's risk-taking and decision-making power and resilience, improve self-confidence, motivation and concentration, and develop children's social, teamwork and citizenship skills (Harris, 2018; O'Brien \& Murray, 2007; Blackwell, 2015; Roe \& Aspinall, 2011; Hordyk, Dulude \& Shem 2015). The findings of research by Cumming and Nash (2015) in Australia provide evidence that these schools can strengthen children's sense of belonging and relational connections. In Turkey, Forest School strategies contributed to improve students' curiosity, self-confidence, creativity, and sense of responsibility, while providing an atmosphere for research and discovery (Bal \& Kaya, 2020). In UK, the British government has stated that 'there is strong evidence that good quality learning outside the classroom adds much value to classroom learning' (O’Brien \& Murray, 2007).

\section{METHOD}

\section{Qualitative Data Collection}

This study is based on a mixture of Farsi and English news media sources, not all available in translation. These primary materials covering the period of 20142019 are supported by available secondary sources in academic journals and other commentary. We have not tried to capture the diversity of social media sources such as Facebook. The value of such alternative views is their non-official status. At the same time, the heterogeneity of political opinions and possible inaccurate representation of information has meant caution using such material.

The broader probative value of contemporaneous documents and citations of public statements made by officials involved in the educational policy offers more robust yet accessible insights into changes in Iranian national educational curricula settings.
Clearly a longer historical perspective may depoliticize positions and allow more measured and fuller expansion of the present dataset, documenting attitudes and changes in how Nature Schools have been viewed over time by NGOs, schools, regional authorities and departmental authorities.

\section{Data Analysis}

The main collected documents were analysed and then summarized in Table 1 below which builds a picture of the strong growth of the Nature School movement over the 2014-2019 period. Duplication of information is avoided by using thematic analysis of the cited sources and additional documents confirming or expanding on points made in the main documents (Alhojailan, 2012; Clarke \& Braun, 2013). Some cited sources appear only in the references list and others are discussed in the main text. Themes derived from the data provide an overview of pressures within the Iranian educational sector, both for change and also resisting change.

\section{RESULTS AND DISCUSSION}

Results are presented and discussed under the following themes: founding of the Nature Schools in Iran, how the Nature Schools released a new educational impetus for innovative teachers, children and their families, the careful government consultation and design setting up the nature schools in cooperation with both Ministry of Education and Department of Environment support, the alternative curriculum in nature and school children outdoors, and the growth pattern of the Nature Schools in the period 2014-19.

\section{The Founding of the Iranian Nature Schools}

The idea of Iranian Nature Schools began well before 2014 with the work of Professor Abdolhossein Vahabzadeh, a university ecologist and recognized environmental academic in Iran. Given the subsequent unfolding of events around the Nature Schools, his position in Iran as founder of the movement is important to understand. Vahabzadeh (2016, p. 1) was born in 1947 (1326 Jalali calendar):

He received his master's degree in ecology from Iowa State University and has been teaching ecology and biology at various Iranian universities for 40 years. He has won the Book of the Year of the Islamic Republic three times so far. In 2005, he won the National Environmental Award of Iran and in 2006, he received the Mehregan Alam Award for his book 'Variety of Life.' In 2008, he was introduced as one of the thirty environmental servants of Iran. Vahabzadeh has spent a significant portion of 
his time translating authoritative books in the biological sciences, focusing on ecology, the environment, and behaviorism, which has resulted in the publication of more than 25 books. His latest book is 'Child and Nature.'

Internationally, various forms of Nature Schools or Forest Schools had been started much earlier in the twentieth century around the world (Hammerman, 1987; Cree \& McCree, 2013; Waite, Bølling \& Bentsen, 2016). Vahabzadeh knew of the European experiences as well as the North American developments. With his professional and environmental focus and wide public connections across Iran, Vahabzadeh was thus well-placed to develop the Nature Schools movement.

The first Nature School started after several years running a small program in Mashhad city called 'The Trips of Mr Worm', supervised by Vahabzadeh and involving teachers and colleagues (Vahabzadeh, 2015; Kavikonj, n.d.). The iterations of this program laid the foundation for the development of the network of Nature Schools in Iran. At that time, few imagined that during the following few years, this small group would stimulate the formation of a new environmental discourse throughout the country beyond the immediate successes of establishing nearly 100 Nature Schools in various Iranian cities and regions (Mirzadegi, 2019):

These schools, which started operation in 2014, were founded by Dr. Abdolhossein Vahabzadeh, along with a number of other Iranian environmental experts and activists who cared deeply about environmental issues. Dr. Vahabzadeh is a prominent Iranian environmental scientist who completed his studies in environmental sciences at U.S. universities and has been teaching for the last 40 years.

Fadaee (2018) adds "The theorist and promoter of the idea of Nature Schools in Iran is Hossein Vahabzadeh, an ecologist with many years' experience teaching and writing about the topic." In Vahabzadeh's mid-2015 presentation, The School of Nature, he reflected on his ideas about learning, education and environmental developments that over time had led to the establishment of Iranian Nature Schools (Vahabzadeh, 2015):

For the last few years, a couple of environmentally concerned people and I have put together nature-trips for children. The children gave it the name 'The Trips of Mr. Worm.' In these trips children are taken to a natural setting accompanied by an adult guardian. Once there, parents let go of their kids and the kids are free to play and frolic about as they wish. The enthusiasm these kids showed in these trips and the interest their parents showed, inspired us to establish the first school of nature in Mashhad.

Vahabzadeh described the first Nature School in Mashhad as having then been going for nine months, and he invited his audience to speak with the school manager "if you wish to obtain more information from him."

The sense of a social or educational movement speaking to an unmet need can be seen in Vahabzadeh's (2015) positioning within the environment-educational sector over a long period of time:

The organizations and authorities who we thought were going to impede us-the Nature School does not have a legal status in Iran yethave reached out to us, shown interest in our work and ask to be a part of this: the Department of Education, educational organizations and municipalities. Many charities have expressed interest in being a part of this project and many schools have brought their students to the school of nature at least once and are interested in turning this into a routine.

Nature Schools were targeted at the formative years of early and primary schooling where there are fewer imperatives to concentrate on examinations or academic technical knowledge, instead laying a foundation for later school learning (Vahabzadeh, 2015):

Parents have shown such an interest. Some are praying for more schools of this kind. What the school of nature aspires to, is for our kids to have, during this critical period before the age of 12 , a lively, joyful, uncontrolled experience, without any direct instruction, to be able to explore, discover and imagine, play with friends, real or imaginary, in nature, and through this game, this creative interaction, a relationship can arise with nature, that is loving, passionate and affectionate. If this love and passion was there it can lay the groundwork for further conscious layers in the following years. But please remember that, if the ground layer is not there all the volumes in a library and all of our instructions about the benefits of innovation, and creativity, about the importance of nature and the environment, will not have the slightest effect once they are adults. At that point, the car has already run out of gas. So, let's put some gas in it. Let's look out for our children. 
The establishment of the Iranian Nature Schools thus had at least four proximate causes stimulating its commencement. First, the work of Vahabzadeh and colleagues as professional ecologists and educators with an expansive view of the need for generational education about environmental issues. Second, the formal institutional agreements of the two key government departments responsible for environment and education. Third, the cluster of conservation and sustainability groups and charities active about the environmental needs of Iran and impacts of climate change globally. Fourth, a desire by many parents to round out their children's learning in contrast to either or both of the top-down formal religious instruction or competitive pressures within Iranian schooling generally (Shobeiri, Meiboudi \& Kamali, 2014; IHRM, 2019).

Nature Schools Released a New Pedagogical Practice The original project before the Nature Schools commenced was a series of locally organized nature trips for small groups of children in Mashhad. During these trips, children safely explored natural environments during the final days of the school week and were allowed free and spontaneous activities in natural settings. Vahabzadeh's group members arranging these trips and facilitating them with him were professionally immersed in environmental scholarship from around the world, keeping abreast of climate and environmental concerns and issues world-wide. The group based its efforts on recent pedagogical shifts in teaching and learning practices in environmental education such as the Forest and Nature Schools in Europe (Jeronen, Jeronen \& Raustia, 2009) and North America (Brownstein \& Ravensbergen, 2012). Vahabzadeh's group eventually established the first Nature School in Mashhad, called the Kavikonj Nature School (Zarghami \& Seyed, 2019; Vahabzadeh, 2016). With support from the Department of Education, the school launched in 2014 as the first step in building a model for Nature Schools throughout Iran.

Vahabzadeh wanted to encourage children's interest to individually and collectively enjoy interacting with their physical environment. Of key importance in these schools was preventing educators from imposing a didactic style of instructing children directly. An overseas Forest School expressed a similar stance, as an "approach to early childhood education that was child-led and play-based, with adults as facilitators not teachers" (Happy Acres, 2020). The intention was to give children the opportunity to learn about different aspects of nature on their own or in collaboration with other children, to strengthen their curiosity, creativity and problem-solving skills (Noaparast,
2018). The Nature School founders believed these schools should avoid exposing children to negative aspects of nature such as hunting, killing animals or deforestation. Since these urbanized children had little direct experience of nature, their reaction would be fear and despair, distancing them from nature rather than inviting and extending their interest and learning (Kavikonj, n.d.).

Instead, Nature Schools were designed to literally include spaces and platforms on which children create and tell their stories. Examples included the following: the balance games platform, the social interaction platform, the animal interaction platform, the wildlife platform, the cultivation and harvesting platform, the natural material, tools and equipment platform, and the closed or cosy environments platform (Kavikonj, n.d.). The literature on significant life experiences shows the importance of nature experiences in childhood (Chawla, 1998; Torkar, 2014; Caplow \& Thomsen, 2019). Eventually, over ninety Nature Schools were registered and began to operate throughout Iran, each accessing localities that safely exposed children to the outdoor environment. They were highly successful in giving children space for interaction and testing ideas (Tasnim News, 2016; IRNA, 2018b, trans. author from Farsi).

Each school had several facilitators. The school facilitators created a safe environment for children. Sometimes facilitators simply watched children from a distance, sometimes they played with them. Sometimes a facilitator would open a new window of possibility for a child, or possibly divert the way a child was trying to achieve something, helping another experience to open up (Kavikonj, n.d.). At the stage that fifty Nature Schools had been established, the Shahrvand Dailyreported from the opening event of the Fasham Nature School, citing Vahabzadeh's philosophy (IFP, 2017):

'3-to-12-year-old children do not need direct education. They will get the chance to get an education later on. Direct education stifles creativity and keeps creative skills in children from developing,' the school principal quotes Vahabzadeh as saying. Nature Schools were first introduced in Europe. Then Vahabzadeh, a renowned environmental activist, brought the idea to Iran.

This news report stated Iran was the first middleeastern country to establish Nature Schools.

Fadaee (2016, p. 21) explained the pedagogical components. It "consists of different spaces such as an eco-farm and a workshop for children to incorporate environmental values while interacting 
with earth, animals, trees, etc." As the Nature School movement grew, its combination of educational and environmental ideas was tested in different places. As these were increasingly accepted, the originating ideas driving the movement were discussed more widely. A documentary by film-maker Khakshoor (2016) interviewed Vahabzadeh and followed him visiting schools and discussing his overall philosophy and intention in engaging children with the outdoors. The documentary has English language captions for non-Farsi speakers, but no English transcript. One report summarized Vahabzadeh's philosophic and pedagogical vision as follows: "Nature Schools play a significant role in improving people's environmental literacy, knowledge and understanding of the environment and the circumstances and conditions affecting it" (MQ/MG, 2017a).

If the internal learning benefits to be gained in Nature Schools were to be more fully realized, enabling them to grow past being just day trips and beyond one-off adventures, these local positive experiences required substantial institutional and organizational leverage. Clearly there was a welcoming demand from urban parents and their children who responded well to exposure to the outdoor environment in these Nature School settings. Further, despite the didactic, teacher-centred educational practice common in Iran, many teachers were just as hungry as families and children to be involved in a different mode of pedagogy. For them, schooling that enabled and allowed new forms of communication and learning, less controlled and directed, meant children would benefit from outdoor contact with the environment in building their educational foundations and creativity.

Government Consultation and Design with Departmental Support

The dramatic rise and subsequent stopping of growth of Iran's Nature School movement can obscure the careful planning and deep involvement of government departments in strategizing nationally to lift the educational development and environmental awareness of school children across Iran. Nature Schools were required to registered with and be approved by the Ministry of Education. The guidelines from the initial Department of Education and Education Ministry memorandum of understanding provided the framework for the schools. As the Financial Tribune (2017a) reported, "Educational Packages' from the [Department of Education] support the goal of establishing many Nature Schools" within the Department of Education's multi-pronged approach to improve environmental understanding and outcomes. This had been consistent departmental policy for more than a decade before 2013: "At the time, the Department of Education developed the educational package to be used in schools for children and adolescents in the age groups 3 to 18," that is, the policy ambition extended beyond the Nature Schools and aspired to include the full age-range of students to the end of high school.

By the time of this Tribune (2017a) report, "educational nature-based programs that provide a practical experience of the environment for children aged 3 to 12 are provided by trained nature teachers from Department of Education, State Welfare Organization (SWO) and University of Social Welfare and Rehabilitation Sciences in Tehran." In the present article we have not established what training or accrediting procedures were developed or used as the criteria for selecting teachers. The IFP (2017) article notes that the Department of Education, "offers good loans to those who build Nature Schools." Clearly, detailed and complex organizational preparation for the commencement and roll-out of the schools in Iran continued at the government departmental level.

The international story, too, blends with the efforts by Vahabzadeh, educators and government officials. As the Tribune (2017a) commented, "The development of Nature Schools in Iran has lagged behind the rest of the world. The first nature preschool in the US opened in 1967." A global movement of rapidly urbanized city populations was losing touch with the biophysical environment familiar even one generation ago. A key policy spokesman from the Iranian Department of Education acknowledged that Nature Schools had been spreading internationally: "over [the] past 30 years in countries such as Finland, Sweden, Norway and Denmark and then the US, Canada, Japan, Indonesia and Malaysia." Many case studies of specific schools and countries appear in the literature, such as Tilbury et al.'s (2005) review of Australian environmental education.

The Department of Education's task was to connect the reality of damage to Iranian landscapes and waterways with changed educational understanding of these environmental harms-for instance, the Department of Education's concern for the 50,000ha of forestry lost every year and other unsustainable activities. The Tribune (2017a) noted:

Lessons on environment protection will soon enter the school curriculum, the head of Education Office at the Department of Education said. Speaking to ISNA, Kioumars Kalantari also said educational material on environment conservation includes three simple teaching packages for pre-school, for first to 10th grade and a separate course book for 11 th grade. 'The 
content has been designed in collaboration with Department of Education's experts and is aimed at making students consider one of the troubles facing Iran's environment at the end of each chapter,' he said. The purpose of the plan is to familiarize society with environmental issues and ways of protecting it, from the very first stage of education. It can also help educators and students develop a deeper understanding of ecological issues and realize the importance of environmental conservation.

The Department of Education's mission and purpose was thus being addressed at several levels. Nature Schools can be seen as important parts of the jigsaw the department was tasked with solving. But clearly other pieces were being developed to fit into the overall objectives.

A snapshot of this broad, iterative national planning of environmental programs is evident a year earlier (Tribune, 2016b):

[The] scheme drawn up by the Department of Education to add environmental education to the curricula of schools nationwide could go into effect as early as September 22 (beginning of the new academic year), according to Department of Education chief, Massoumeh Ebtekar. The official was quoted by PANA as saying that her department is working closely with the Ministry of Education to fast track the implementation of the scheme in 110,000 schools across Iran. 'Students and teachers can help address our environmental problems,' Ebtekar said, adding that the scheme will help educators and students develop a deeper understanding of ecological processes and understand the importance of environmental conservation. Last year, as part of the plans for environmental education, the ministry introduced 60 environment schools (known as JAM Schools in Persian) with the collaboration of Department of Education.

The Nature Schools fitted very comfortably into this larger environmental educational remit. At the opening of 50th Nature School, a key departmental official stated that "The creation and expansion of Nature Schools is in line with the 20-year national development plan (ending in 2025) with the goal of creating about 1.5 million job opportunities in the country" (SB/MG, 2017b).

An Alternative Curriculum in Nature with School Children Outdoors

Descriptions of Nature Schools indicate a variety of opportunities and staff resources that individual locations could bring together (Gharahbeiglu, 2007).
A study by Zarghami and Seyed (2019, p. 387) found that for Nature Schools, 'children's 'imagination' is the foremost driver of their spatial choices and movements." The Financial Tribune (Tribune, 2017b) reported children's outdoor activities as follows:

Children are feeling the trunk of a tree with their eyes blindfolded; a happy smiling girl is cherishing a rabbit, and some other children are watering flowers planted in a corner in the yard. These are some of the pictures taken at a Nature School in the country. There are no school benches, no books or pencils.

The experiential learning of the outdoor nature space, according to Fadaee (2018) shifts environmental comprehension:

These schools consist of different spaces such as vegetable-gardens, animal farms, ponds and forests. The objective of these spaces is to facilitate the interaction of children with the natural environment. Ideologically, these schools criticize rapid urbanization, the destruction of natural habitats and environments, and the proliferation of environmentally unfriendly habits and behaviors.

The Department of Education view expressed publicly as the Nature Schools were rapidly expanding was predicated on this exposure to the outdoors (Tribune, 2017b):

According to [Department of Education spokesperson] Darvish, each school should be established on land with an area of at least two hectares. Children under the age of seven can be enrolled fulltime in the schools (instead of being enrolled in kindergartens). The teacher-tostudent ratio is 1 to 5 . Nature teachers have been employed to supervise and give an appropriate direction to children's activities in the environment; student-driven activities surpass teacher-directed programs. Children over the age of seven from other schools can visit the Nature Schools for half a day per week. Children can be brought to the schools by their parents or by their regular school teachers, Darvish said. 'This way, regular schools can integrate nature education into their curriculum.'

Darvish, deputy of education and public participation at the Department of Education, is cited in the same article at length to show a bigger departmental vision in play (Tribune, 2017b): 
'The idea behind the schools is to encourage and inspire children of different ages through positive outdoor experiences. Most of the schools have been established in the vicinity of farmlands, near birds' nesting places, trees, and other areas where wildlife can live in harmony alongside humans,' he said. 'Nature-based programs cannot be provided in regular school settings and that is why the Department of Education is making every effort to increase such schools across the country.

At each Nature School opening ceremony the media reports show the Department of Education restating its environmental strategy and outdoor philosophy for the foundational stages of education. The extended statement above immediately segues from describing the value of environmental teaching and learning context, to the value of developing personal traits (Tribune, 2017b). Nature Schools:

also aim to develop self-awareness, selfregulation, intrinsic motivation, empathy, good social communication skills, independence, selfesteem and confidence in children and adolescents,' he said. The schools have two guiding principles in their programs: connecting deeply with nature through practical participation, and exploring the environment as co-learners.

Most educationalists, especially outdoor instructors, endorse this conjunction of environmental learning outdoors with developing personal skills (Mansouri \& Ghare Bigloo, 2012). The departmental statement above, appropriately enough, even makes these "two guiding principles" notion explicit. Why, later in 2018-2019 the government reversed course and began to close the majority of the Nature Schools is not clear. Accounts might well start with the success of this broad outdoor pedagogical vision competing too well with formalized indoor emphasis on achievementoriented academic or formal religious pedagogies in primary education.

\section{Growth Pattern of Nature Schools}

The Nature School movement grew rapidly, in towns, cities, as well as in more rural towns and regions; the locations can be traced on the Iranian Nature Schools national website (Nature Schools Iran, 2020). As well as clear leadership, administratively the movements' progress might be described as based on the through and detailed preparation work. On the supply-side, this preparation was focused on the environmental and educational framework, and the institutional involvement of government agencies. On the other hand, the unmet needs of urban families and children, along with professional opportunities that teachers were seeking, created a strong demand-side.

Contemporaneous Iranian news outlets information is presented in Table 1, successive data points giving an overall perspective of the growth trajectory of the Iranian Nature Schools in the 20142019 period. This can be interpreted within political contestation at departmental and regime levels, at first positively enabling growth and then later being reversed.

Some schools were mobile-by August 2017 there were 17 mobile Nature Schools. These kinds of schools were not permanently set in specific places. They usually had weekly schedules or monthly trips, adapting to local needs and resources available in applying the concept and principles of Nature Schools. For example, one mobile school took children to and around natural settings every week. Another mobile school used a particular part of an urban park, children going there to play every Monday to literally touch different kinds of animals, to build animal "houses," and so on.

The data from Table 1 can be visualized as an scurve of increase in schools, growing rapidly after the first period of establishing the value of individual Nature Schools. Over time the success of the schools' multiplication and creative freedom in learning became a problem for the conventional educational system. In 2018 the Ministry of Education started refusing licenses to open new Nature Schools, and withdrawing licenses from existing schools. The energy and efforts of officials in the Department of Education had been sustained over many rounds of planning and curriculum development, funding arrangements in the approval process. It must have been a severe disappointment administratively and in terms of the department's vision of environmental education for Iran. The Department of Education's strategic work in education, beyond the Nature Schools, nevertheless included curriculum development of textbooks and professional accreditation of teachers for all school levels.

Vahabzadeh's philosophy was not simply some esoteric love of nature, but awareness of the societal reality of Iran having experienced rapid modernization that included dramatic levels of urbanization, expansion of the educational sector, and a rapid demographic transition from larger to smaller families typical of modern societies. The Islamic Republic a decade after coming to power, "deployed a series of contraceptive and counselling services that [became] one of the world's most effective voluntary family planning programs" shrinking families from 5.5 to two children per woman (Cincotta \& Sadjadpour, 2017, p. 7). An irony 
Table 1. News sources showing growth of nature schools

\begin{tabular}{|c|c|c|c|}
\hline Month & $\mathrm{n}$ & Note & Source \\
\hline $\begin{array}{l}2014 \\
\text { December }\end{array}$ & 1 & Established in Mashhad City by Hossein Vahabzadeh and colleagues. & $\begin{array}{l}\text { Fadaee (2018, p. } \\
\text { 21) IRNA (2018a) }\end{array}$ \\
\hline $\begin{array}{l}2016 \\
\text { July }\end{array}$ & 11 & $\begin{array}{l}\text { "Following the launch of } 11 \text { environment schools across the country, } \\
\text { the Department of Education is now set to establish nine more by the } \\
\text { end of the current Iranian year (March 2017)" }\end{array}$ & Tribune $(2016 a, b)$ \\
\hline $\begin{array}{l}2016 \\
\text { September }\end{array}$ & 20 & $\begin{array}{l}\text { "We are planning on increasing them to } 40 \text {, twice as many as the current } \\
\text { number by the end of the year"; "number of Nature Schools would } \\
\text { double by the following March 2017." }\end{array}$ & MQ/MG (2016) \\
\hline $\begin{array}{l}2016 \\
\text { December }\end{array}$ & 29 & $\begin{array}{l}\text { "Last year [2015]... [Department of Education] introduced } 60 \\
\text { environment schools (known as JAM Schools in Persian)." }\end{array}$ & Tribune (2017b) \\
\hline $\begin{array}{l}2017 \\
\text { February }\end{array}$ & 42 & "Opened in Pardisan Park, northwestern Tehran." & MQ/MG (2017a) \\
\hline $\begin{array}{l}2017 \\
\text { May }\end{array}$ & 46 & $\begin{array}{l}\text { "Nature Schools across Iran have created about } 500 \text { jobs, Masoumeh } \\
\text { Ebtekar, the chief of the [Department of Education] announced." }\end{array}$ & SB/MG (2017a) \\
\hline $\begin{array}{l}2017 \\
\text { August }\end{array}$ & 50 & $\begin{array}{l}\text { Includes } 17 \text { mobile Nature Schools; "Chief of [Department of Education] } \\
\text { Masoumeh Ebtekar [spoke at] the inauguration ceremony." }\end{array}$ & $\begin{array}{l}\text { SB/MG (2017b) } \\
\text { MQ/MG (2017b) }\end{array}$ \\
\hline $\begin{array}{l}2018 \\
\text { July }\end{array}$ & 77 & "Establishment of such schools is underway in other provinces." & IRNA (2018b) \\
\hline $\begin{array}{l}2019 \\
\text { August }\end{array}$ & 90 & $\begin{array}{l}\text { "90 Environmental schools have been closed by the Islamic } \\
\text { government." }\end{array}$ & Mirzadegi (2019) \\
\hline
\end{tabular}

of this low birth-rate achievement is the contrast between fundamentalist religious governance emphasizing traditional, largely rural, family values, while family mores and urban expectations were moving in quite different directions. Arguments whether these values are inherently incompatible or reconcilable is never final.

Environmental learning was also argued for by Department of Education officials on pedagogical grounds as needed for educational development in Iran generally (Tasnim News, 2016):

According to Darvish, the general director of the Office of Education and Public Participation of the Department of Environment, the outcomes of these schools show that the percentage of hyperactivity of students has decreased, their learning rate has increased, and even children with autism have shown signs of improvement in these schools. These schools do not have a bell, they do not have walls, they do not have direct education and teachers, children experience nature by touching nature, their creativity grows and they gain self-confidence. There is no competition or comparison, children have the opportunity to touch the soil, play with water and flowers, and have a happy memory of nature. Children who grow up like this love their homeland. In adulthood, these children never bring their car windows down to dump garbage, they are never indifferent to forest fires, they never shoot at wildlife under the pretext of having fun.

It is not possible yet to say conclusively what elements of the Nature School pedagogy or philosophy caused the defensive official reaction to the schools. In many ways it is equally possible within an Islamic worldview that recognition of divine care of nature is coupled with humankind's appropriate behavior and learning within nature.

\section{Contested Development for the Nature Schools}

Another irony, then, is that power to close Nature Schools inflicted damage on the continuing developmental efforts to create modern Iran. The national project is to achieve modern nation-building, while also attempting to retain traditional cultural and religious values. Some modernization forces push back and some construct new syntheses of changing socio-economic and socio-demographic realities. Both forces operate within a series of competing, and sometimes contradictory, internal and external pressures: philosophy and faith, labour market and employment, education and environmental global citizenship.

Despite cutbacks some Nature Schools remain open, including mobile Nature Schools. The changed appointees as the heads of the Department of Education and Education Ministry started rejecting new approvals of Nature Schools in 2018, then withdrawing licenses, so that more than half had 
closed by the end of 2019. The new head of the Department of Environment revoked licenses of schools without prior notice (Kari, 2019). Various reasons have been given for closing these schools, for instance, in one statement the Education Ministry said the activities of Kavikonj Nature School did not fit within the framework of education laws (Salamat News, 2018). On 14 August 2019 the head of the Iranian Department of Environment announced that Nature Schools were illegal, did not have any formal authorization, and religious authorities viewed these schools as promoting non-religious ideologies (Radiofarda, 2019; Khabaronline, 2019).

The previous Department of Education head had attended and spoken positively at Nature School openings, as had other senior Department of Education officials. Now, however, according to the Deputy Minister of Education, the goals of these schools were not compatible with Islam. No evidence was produced justifying how contacting nature and the outdoor environment contradicted Islamic principles. Similarly, Mirzadegi (2019):

Early this week, Isa Kalantari, the director of Iran's Department of Environment, called the continuation of 'environmental schools' illegal, cancelling their licenses and preventing them from continuing operation. Since last year in fact, half of these environmental schools have been closed by the Islamic government and permits for opening new schools, granted in the past, have also been revoked. Kalantari has stated the reason for the suspension of these schools as 'religious' or due to a lack of religious teachings.

Today Iranian Nature Schools identified on internet maps show school names, telephone numbers and Iranian language websites, but sadly, alongside each entry is the red script: "Temporarily closed."

Malekzadeh (2011, pp. iii-iv) avoids western-style critique, aiming at a longer-term understanding of the development of the education system within Iran. The abrupt closure of Nature Schools in this framework demonstrates, "the incoherent and contested nature of the New Islamic Citizen":

Competition between rival groups for the moral authority to insert their vision of the ideal Islamic society into the education system accounts for the variation in the political and religious content of formal education. These ongoing and unresolved conflicts have resulted in a post-revolutionary curriculum layered with contradictions and tensions that in turn provide students with the resources and opportunities to challenge the totalizing project of the state.
This is a similar argument Mehran (1990, p. 57) makes, that "Another important goal of the cultural revolution in Iran has been the transformation of the Westernized person into an Islamic one who is proud of his/her heritage." In Mehran's view in the current Islamic Republic instantiation this goal is a permutation of Iranian modernization over a period of two centuries. On this understanding, "The educational system, therefore, must bring about rejection of Western values and create a sense of pride and glory in being part of an Islamic culture that is presented to the school-children as being 'morally superior' to the West."

This creates complexities for a development process that can get caught in both internal Iranian competition and external-to-Iran geo-political and economic binaries that impact progress in establishing a robust contemporary educational system. Mirzadegi (2019), in some detail, joins the dots between contested social change, education, environment, politics and religion:

It is clear that the popularity of these Nature Schools has angered the Friday Prayer Imams and other religious authorities. In these schools, compulsory religious studies, which have been the hallmark of public and private education in Iran for the last 40 years, were not taught. Children and adolescents spent their time learning about nature and the environment instead of going to mosques.

Thus, there are longer-term cultural pressures as well as the contemporary political need to govern, and more immediate government sensitivities.

During the establishment of Nature Schools there was constant public refrain by Department of Education officials that: "The Nature School is not interfering with the normal school operating under Education Ministry's supervision, rather it is a place for the children to spend their free time and enjoy environmental activities there with their parents" (MQ/MG, 2016). This was recognition of educational or learning needs not being met by the religiously controlled, curriculum and competition-driven ethos of Iranian education. Simultaneously reading the downward trajectory can also be interpreted as a consciousness of pushing the discursive boundaries promoting environmental education (EE) in resistance to top-down religious orthodoxy. There will undoubtedly have been politics between and inside departments about the broad control of religious education, perhaps big personalities, local spheres of influence or career rivalries.

It was thus a shock to observers to see this vibrant and growing educational movement suddenly 
eclipsed, its growth trajectory stopped because of government concerns about the strategy and focus of Nature Schools. However, there are still a few Nature Schools remaining open. There has not been a clear indication of reasons for stopping the growth of these carefully planned and well-run Nature Schools established in scores of places across Iran. Nature Schools added credibility to Iranian education, they were popular with parents and children, and they strategically innovated in offering pedagogicallyrounded learning environments.

\section{CONCLUSION}

The present article has provided a brief outline of the Iranian Nature Schools movement. Gathering official documents as well as first-person accounts from a variety of sources, especially Farsi language material, would allow a much larger and more detailed account of this history to emerge, integrating more fully the educational, employment and environmental changes in Iranian society as it continues to develop. Iran has become a very different country in the century since the Qajar Dynasty ended in 1925. Critique of the ecological inadequacy of midtwentieth century Iranian education, and the changed living situations of modern urbanized families since then in Iran, have led to substantial disconnection of children and their natural environment. Nature Schools offered, and were effective in, creating links between children and nature. Iran shares these issues with other countries modern and modernizing, and one common educational experiment internationally has been the place of natural or school settings for environmental learning.

Despite the eclipse of the Iranian Nature School movement, a longer time-frame suggests positives. First, at the same time Nature Schools were being shut down, green high schools or eco-schools were being established throughout Iran and new environment curricula rolled out (FB/MG, 2019b). It appears that the broader dialectic of social and modernizing changes that saw the advent of Nature Schools, continues despite their shutdown, jostling to find new avenues of expression. The same youth cohort progressing though higher levels of education, continues to learn about the environment and humans' place within it. A second positive continuation of the Nature Schools legacy can be seen in institutionalizing the environmental focus in preschool education throughout the country (FB/MG, 2019a). The new national environment education curricula, the age-stepped school textbooks series that has been developed with the Department of the Environment and Ministry of Education is now available, and the growing environmental understanding of teachers, all point in the opposite direction to the Nature Schools' closure.

\section{REFERENCES}

Alhojailan, M. I. (2012). Thematic analysis: A critical review of its process and evaluation. West East Journal of Social Sciences, 1(1), 39-46.

Arvidsen, J. (2018). Growing dens. On re-grounding the childnature relationship through a new materialist approach to children's dens. Children's Geographies, 16(3), 279-291. https://doi.org/10.1080/14733285.2018.1425371

Bal, E., \& Kaya, G. (2020). Investigation of forest school concept by forest school teachers' viewpoints. International ElectronicJournal of EnvironmentalEducation, 10(2), 167180.

Blackwell, S. (2015). Impacts of long term forest school programmes on children's resilience, confidence and wellbeing. Acesso em, 30(04), 1-46.

Behroozfar, F. (2001). The basics of designing open spaces of the residential areas in concordance with the physical and psychological conditions of the children. Tehran Residential Investigation Center Press.

Brownstein, D., \& Ravensbergen, S. (2012). Outstanding environmental education programs in North America. Department of Geography, University of British Columbia.

Caplow, S., \& Thomsen, J. (2019). Significant life experiences and animal-themed education. In Animals in Environmental Education (pp. 237-257). Palgrave Macmillan, Cham.

Chawla, L. (1998). Significant life experiences revisited: A review of research on sources of environmental sensitivity. The Journal of Environmental Education, 29(3), 11-21. https://doi.org/10.1080/00958969809599114

Cincotta, R., \& Sadjadpour, K. (2017). Iran in transition: the implications of the Islamic Republic's changing demographics (pp. 1-36). Carnegie Endowment. https://carnegieendowment.org/files/CP324_Iran_in_Tra nsition_Final.pdf

Clarke, V., \& Braun, V. (2013). Teaching thematic analysis: overcoming challenges and developing strategies for effective learning. The Psychologist, 26(2), 120-123.

Cree, J., \& McCree, M. (2013). A brief history of forest schools in the UK-part 2. Horizons Magazine, (62), 32-35.

Cumming, F., \& Nash, M. (2015). An Australian perspective of a Forest School: Shaping a sense of place to support learning. Journal of Adventure Education and Outdoor Learning, 15(4), 296-309. https://doi.org/10.1080/14729679.2015.1010071

Darling-Hammond, L, Flook, L., Cook-Harvey, C., Barron, B., \& Osher, D. (2020). Implications for educational practice of the science of learning and development. Applied Developmental Science, 24(2), 97-140. https://doi.org/10.1080/10888691.2018.1537791

Fadaee, S. (2016). Rethinking southern environmentalism. In Understanding southern social movements (pp. 15-26). Routledge.

Fadaee, S. (2018). Environmentalism and social change in Iran. In R. Barlow \& S. Akbarzadeh (Eds.), Human rights and 
agents of change in Iran: towards a theory of change (pp. 153-156). Palgrave Macmillan.

FB/MG. (2019a, 14 September). Environmental education to be included in pre-primary schools. Tehran Times. https://www.tehrantimes.com/news/440128/Environm ental-education-to-be-included-in-pre-primary-schools

FB/MG. (2019b, 22 October). First 'green school' inaugurated in Tehran. Tehran Times. https://www.tehrantimes.com/news/441406/Firstgreen-school-inaugurated-in-Tehran

Gharahbeiglu, M. (2007). Children's interaction with urban play spaces in Tabriz, Iran. Visual Studies, 22(1), 48-52.

Hammerman, W. M. (1987). The impact of outdoor education on American Education. Journal of Outdoor Education, 21, 4-14.

Happy Acres. (2020). History of Forest Schools. https://www.happyacresforestschool.com/history-offorest-schools

Harper, N. J. (2017). Outdoor risky play and healthy child development in the shadow of the "risk society": A Forest and Nature School perspective. Child \& Youth Services, 38(4),

318-334.

https://doi.org/10.1080/0145935X.2017.1412825

Harris, F. (2017). The nature of learning at Forest School: practitioners' perspectives. Education 3-13, 45(2), 272291. https://doi.org/10.1080/03004279.2015.1078833

Harris, F. (2018). Outdoor learning spaces: the case of Forest School. Area, 50(2), https://doi.org/10.1111/area.12360

Hedayati, F. (2018, 7 April). Children's needs and urban spaces. ttp://www.iribnews.ir/fa/news/2061113/- نيازهاى -كودكان و-فضاهاى شهرى

Hordyk, S. R., Dulude, M., \& Shem, M. (2015). When nature nurtures children: nature as a containing and holding space. Children's Geographies, 13(5), 571-588. https://doi.org/10.1080/14733285.2014.923814

IFP. (2017, 10 August). Nature Schools: Different environment to nurture students. IFPNews. https://ifpnews.com/nature-schools

IHRM. (2019, 30 September). Repressive state and low quality of education in Iran. TrackPersia. http://www.trackpersia.com/repressive-state-lowquality-education-iran/

Imani, B., Yarmohammadi, K., \& Yarmohammadi, K. (2017). Child-friendly cities from the perspective of children (case study: Department of Education Area 1 Ardebil). Journal of Geography and Environmental Studies, 6(21), 7-22.

IRNA. (2018a, 14 July). 1st Middle East Nature School opens in Iran. Islamic Republic News Agency. https://en.irna.ir/news/82970664/1st-Middle-Eastnature-school-opens-in-Iran

IRNA. (2018b). Nature Schools, an opportunity to introduce life skills to children. (Trans. by author from Farsi). Islamic

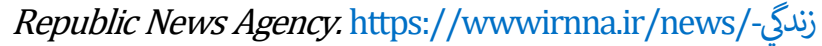
مهارت-با-كودكان-آشناي-براي-فرصتي-طبيعت-مدرسه/2002

Jeronen, E., Jeronen, J., \& Raustia, H. (2009). Environmental education in Finland - a case study of environmental education in Nature Schools. International Journal of Environmental \& Science Education, 4(1), 1-23.

Kari, K. (2019, May 6). What is a Nature School? History, activities and successful examples. https://www.bbc.com/persian/iran-49332125

Kavikonj. (n.d.). Kavikonj: Nature School website http://www.findglocal.com/IR/Mashad/158384381851 1858/

Khodaee, Z, Rafieian, M, Taghvaei, AK \& Salehi Amiri, SR (2015). Effective factors on youth satisfaction from public urban spaces in Tehran, Residential Treatmentfor Children \& Youth, 32(1), 19-36.

Khabaronline. (2019). What closed the schools of nature: the religious issues or the administrators. Khabaronline News Agency. https://www.khabaronline.ir/news - شرعى- مسائل- كرد- تعطيل- را- طبيعت- مدارس- حيزى- خه/ ایى- توده- مديران- يا

Khakshoor, R. (Film-maker). (2016, 2 August). Nature School: documentary on Hossein Vahabzadeh, ecologist and concepteur of Nature School (Farsi with English subtitles). $(40.02$ mins). https://www.youtube.com/watch?v=3Qys4vRKXuc

Leather, M. (2018). A critique of "Forest School" or something lost in translation. Journal of Outdoor \& Environmental Education, 21(1), 5-18. https://doi.org/10.1007/s42322017-0006-1

Lockheed, M. E., Verspoor, A. M. (1991). Improving primary education in developing countries. Oxford University Press.

Lovell, R. (2009). Evaluation of physical activity at Forest School. http://hdl.handle.net/1842/4146

Malekzadeh, S. (2011). Schooled to obey, learning to protest: the ambiguous outcomes of postrevolutionary schooling in the Islamic Republic of Iran. (PhD). Georgetown University.

Manner, J., Doi, L., \& Laird, Y. (2020). 'That's given me a bit more hope'-adolescent girls' experiences of Forest School. Children's Geographies, 1-14. https://doi.org/10.1080/14733285.2020.1811955

Manouchehri, B. (2019). The role of urban planners in inclusion of children in the urban decision-making system: the case of Iran. (PhD). La Trobe University.

Mansouri, S. A., \& Ghare Bigloo, M. (2012). The quality of open space interaction with children. Journal of MANZAR, 5(25), 20-23.

http://www.manzarsj.com/article_5038_a60b2b9182b65eda02c8df6dab5e7 bec.pdf

Maynard, T. (2007). Forest Schools in Great Britain: an initial exploration. Contemporary Issues in Early Childhood, 8(4), 320-331.https://doi.org/10.2304/ciec.2007.8.4.320

Mehran, G. (1990). Ideology and education in the Islamic Republic of Iran. Compare: A Journal of Comparative \& International Education, 20(1), 53-65. https://doi.org/10.1080/0305792900200105

Mirzadegi, S. (2019, 17 August). 90 environmental schools have been closed by the Islamic government. http://worldculturalheritagevoices.org/90environmental-schools-have-been-closed-by-the-islamicgovernment/

MQ/MG. (2016, 25 September). Nature Schools to double in Iran by March. Tehran Times. 
https://www.tehrantimes.com/news/406713/Natureschools-to-double-in-Iran-by-March

MQ/MG. (2017a, 11 February). 42nd Nature School opens in Iran. Tehran Times. https://www.tehrantimes.com/news/410946/42ndnature-school-opens-in-Iran

MQ/MG. (2017b, 15 May). Iran inaugurates 46th Nature School. Tehran Times. https://www.tehrantimes.com/news/413425/Iraninaugurates-46th-nature-school

Nature Schools Iran. (2020). Comprehensive map of Nature Schools in Iran. Nature Schools Iran website. https://natureschools.ir/

Noaparast, K. (2018). Iran's implicit philosophy of education. Educational Philosophy \& Theory, 50(8), 776-785. https://doi.org/10.1080/00131857.2016.1247684

Novo, C. (2019). Iran's water crisis: drought, floods and poor management.

https://smartwatermagazine.com/blogs/cristinanovo/irans-water-crisis-drought-floods-and-poormanagement

O'Brien, L. (2009). Learning outdoors: The forest school approach. Education 3-13, 37(1), 45-60. https://doi.org/10.1080/03004270802291798

O'Brien, L., \& Murray, R. (2007). Forest School and its impacts on young children: case studies in Britain. Urban Forestry \& Urban Greening, 6(4), 249-265. https://doi.org/10.1016/j.ufug.2007.03.006

Pamuk, D. K., \& Ahi, B. (2019). A phenomenological study on the school concept of the children attending the Forest School. Eğitimde Nitel Araştrmalar Dergisi, 7(4), 13861407.

Rantala, O., \& Puhakka, R. (2020). Engaging with nature: Nature affords well-being for families and young people in Finland. Children's Geographies, 18(4), 490-503. https://doi.org/10.1080/14733285.2019.1685076

Radiofarda. (2019). Closing of Nature Schools in Iran, due to the opposition of the imitation authorities and the Ministry of Intelligence. Radio Farda. https://www.radiofarda.com/a/the-school-ofnature/30107600.html

Ridgers, N. D., Knowles, Z. R., \& Sayers, J. (2012). Encouraging play in the natural environment: a child-focused case study of Forest School. Children's Geographies, 10(1), 49-65. https://doi.org/10.1080/14733285.2011.638176

Roe, J., \& Aspinall, P. (2011). The restorative outcomes of Forest School and conventional school in young people with good and poor behaviour. Urban Forestry \& Urban Greening 10(3), 205-212. https://doi.org/10.1016/j.ufug.2011.03.003

Salamat News. (2018). The country's Nature Schools are closed one by one in the absence of law. Salamat News. مدارس-طبيعت-www.salamatnews.com/news/257717 يكى-يكى-تعطيل--80\% 80\% شوند8\%

SB/MG. (2017b, 2 August). Iran's 50th Nature School inaugurated. Tehran Times. https://www.tehrantimes.com/news/415624/Iran-s50th-nature-school-inaugurated
Shahrizadeh, S., \& Moayedfar, S. (2017). Child-friendly strategic planning with emphasis on children's creativity (case study: Yazd City). Research and Urban Planning $8(28), 171-186$.

Sharifian, M. (2018). Early childhood education in Iran: progress and emerging challenges. International Journal of the Whole Child, 3(1), 30-37.

Sheykhi, M. T. (2009). Youth development as a product of social development: a sociological study of youth and development in Iran. Journal of Social Sciences, 18(3), 173181. https://doi.org/10.1080/09718923.2009.11892679

Shobeiri, S., Meiboudi, H., \& Kamali, F. (2014). The brief history of environmental education and its changes from 1972 to present in Iran. International Research in Geographical \& Environmental Education, 23(3), 228-241. https://doi.org/10.1080/10382046.2014.927169

Shokoohi, R., Hanif, N. R., \& Dali, M. M. (2011). Children walking to and from school in Tehran: associations with neighborhood safety, parental concerns and children's perceptions. Asian Journal of Environment-Behaviour Studies, 2(4), 13-25.

Staff, S. (2017). Schools shut in Iran capital, major cities due to high pollution. https://www.reuters.com/article/us-iranpollution-idUSKBN1ED12I

Suidman, S. (2018). Triggering political and Social Change in the Iranian Society (Masters thesis). Wageningen University.

Swarbrick, N., Eastwood, G., \& Tutton, K. (2004). Self-esteem and successful interaction as part of the Forest School project. Support for Learning 19(3), 142-146. https://doi.org/10.1111/j.0268-2141.2004.00337x

Tasnim News. (2016). Nature Schools: a place to teach life to children.

https://www.tasnimnews.com/fa/news/1395/09/18/1

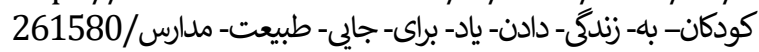

Tilbury, D., Adams, K., \& Keogh, A. (2005). A national review of environmental education and its contribution to sustainability in Australia: business and industry education. Department of the Environment and Heritage.

Tillmann, S., Button, B., Coen, S. E., \& Gilliland, J. A. (2019). 'Nature makes people happy, that's what it sort of means': children's definitions and perceptions of nature in rural Northwestern Ontario. Children's Geographies, 17(6), 705-718. https://doi.org/10.1080/14733285.2018.1550572

Tonucci, F \& Rissotto, A (2001). Why do we need children's participation? the importance of children's participation in changing the city. Journal of Community \& Applied Social Psychology, 11(6), 407-419.

Torkar, G. (2014). Learning experiences that produce environmentally active andinformed minds. NJASWageningen Journal of Life Sciences, 69, 49-55.

Tribune. (2016a, 20 July). Teaching them young. Financial Tribune. https://financialtribune.com/articles/peopleenvironment/45904/teaching-themyoung?utm_campaign=more-like-this

Tribune. (2016b, 20 August). Raising environmental awareness in schools. Financial Tribune. https://financialtribune.com/articles/people- 
environment/48013/raising-environmental-awarenessin-schools

Tribune. (2017a, February 7). Connecting with nature from schooltime. Financial Tribune. https:/financialtribune.com/articles/people/59100/con necting-with-nature-from-schooltime

Tribune. (2017b, 26 February). Nature Schools increase. Financial Tribune. https://financialtribune.com/articles/people/60416/nat ure-schools-increase

Tribune. (2017c, 30 June). Environment to enter Iran school curriculum. Financial Tribune https://financialtribune.com/articles/peopleenvironment/71425/environment-to-enter-iran-schoolcurriculum

Tribune. (2017d, November 25). Tehran Green Spaces Vanishing. https://financialtribune.com/articles/environment/6482 6/tehran-green-spaces-vanishing

UNICEF. (2018). Shaping urbanization for children, a handbook on child-responsive urban planning.

Vahabzadeh, A. (2015, 11 June). The school of nature (18.07mins.) (Farsi with English subtitles and transcript). TEDXKish. https://www.youtube.com/watch?v=oDte6lPfah4

Vahabzadeh, A. (2016, August 30). What is taught to children in the school of nature? /conversation with the founder of Nature Schools in Iran. KhabarOnline. https://www.khabaronline.ir/news/561450/

Waite, S., Bølling, M., \& Bentsen, P. (2016). Comparing apples and pears?: a conceptual framework for understanding forms of outdoor learning through comparison of English Forest Schools and Danish Udeskole. Environmental Education Research, 22(6), 868-892. https://doi.org/10.1080/13504622.2015.1075193

Yates, E., \& Oates, R. (2019). Young children's views on play provision in two local parks: a research project by early childhood studies students and staff. Childhood, 26(4), 491-508. https://doi.org/10.1177/0907568219839115

Zarghami, E., \& Seyed, B. (2019). Natural learning: An observational study of children behavior in Mashhad Kavikonj Nature School. Journal of Technology of Education, 13(3), 387-401. https://doi.org/10.22061/jte.2018.3953.1962 